\title{
VACCINATION OF Y'OUNG CALVES AGAINST TRICHOPHYTOSIS
}

\author{
A. RYBNIKÁR, V. VRZAL and J. CHUMELA
}

Bioveta, 68323 Ivanovice na Hané

Received fune 24, 1992

\begin{abstract}
Rybnikár̆ A., V. Vrzal, J. Chumela : Vaccination of Young Calves against Trichophytosis. Acta vet. Brno, 62, 1993: 55-61.

Calves vaccinated against trichophytosis at 1 to 7 days of age and revaccinated 10 days later showed a satisfactory degree of protection against experimental infection with a virulent strain of Trichophyton verrucosum. The same results were obtained after immunization of calves in groups of older animals (aged 8 to 42 days). All non-vaccinated controls given the same challenge dose showed extensive trichophytic crusts that persisted throughout the observation period.

A field experiment with the same vaccine was conducted in a herd where $50 \%$ of the calves were affected with trichophytosis. New arrivals in the calf-house were vaccinated at 3 to 6 days of age and revaccinated 10 days later. Of 179 vaccinated animals, $4(2.2 \%)$ developed trichophytosis.
\end{abstract}

Trichophyton verrucosum, vaccination, age groups, challenge

Which is the most convenient age at which calves should be vaccinated agains trichophytosis is still an open question. According to some writers (Sarkisov et al. 1976, Zharkov 1985) calves should not be vaccinated until they are 1 month old. Younger animals are regarded by Sarkisov (1979) as immunologically immature and the development of reliable post-vaccination immunity against trichophytosis in these animals cannot be guaranteed. This view, however, was not confirmed by the results reported by other writers (Naess and Sandvik 1981; Yablochnick et al. 1987); immunity was recorded in calves vaccinated with vaccine LTF-130 at 3 to 5 days of age.

In the present study the efficacy of vaccination of young calves with the Czechoslovak freeze-dried vaccine against trichophytosis was tested in challenge experiments and in the field.

\section{Materials and Methods}

Challenge experiments were conducted on calves of the Bohemian Pied Breed divided into 6 groups according to age. The animals were vaccinated with freeze-dried vaccine against trichophytosis produced by Bioveta, Ivanovice na Hané. The vaccine was injected i. m. into the gluteal muscle in two prophylactic doses of $2.5 \mathrm{ml}$ given 10 days apart. One month after revaccination the vaccinated calves and non-vaccinated controls were challenged epicutaneously by rubbing a suspension of Trichophyton verrucosum culture in doses of 5 million CFU onto a $10 \times$ $\times 10 \mathrm{~cm}$ clipped and gently scarified area of the right flank. The animals were then observed for the presence of clinical dermal lesions for 32 days after challenge. At the end of the experiment the positive clinical findings were examined by culture (Sabouraud's agar with actidion and chloramphenicol) and subjected to microscopic examination (staining with Blankophore).

The field experiment was conducted in a bovine herd where vaccination against trichophytosis was carried out regularly in calves 4 to 6 weeks old. Before the experiment was started $50 \%$ of the calves developed trichophytosis within 3 months after birth. Clinical signs of the disease were generally present at the time of vaccination, the first signs being observed as early as 3 weeks after birth. The experimental calves (179 animals) were vaccinated at 3 to 6 days of age and revaccinated 10 days later using the same prophylactic doses of the freeze-dried vaccine against 
trichophytosis as described above and then observed for the following 3 months. The incidence of trichophytosis was compared with that observed in animals of the corresponding age categories before the experiment was started.

\section{Results}

The results of challenge experiments are shown in Tables 1 to 6 . It can be seen that all vaccinated calves, irrespective of their age at the time of vaccination, developed a satisfactory degree of post-vaccination immunity which protected them from experimental infection with trichophytosis; after challenge, trichophytic foci were either absent or were only minute, superficial in character and of short duration (Plate XV., Fig. 1 and 2).

All non-vaccinated controls given the same challenge dose developed clinical trichophytosis, showing mycotic changes at the challenge site which affected even the deep skin layers. These trichophytic foci persisted till the end of the experiment (Plate XVI., Fig. 3 and 4).

In the field experiment $4(2.2 \%)$ out of the 179 calves given the first vaccination at 3 to 6 days of age showed solitary trichophytic changes which appeared 1 month after birth. The remaining vaccinated calves showed no clinical signs of trichophytosis throughout the observation period.

\section{Discussion}

In bovine herds with the incidence of trichophytosis calves are exposed to the risk of being infected with virulent strains of the genus Trichophyton as soon as they are born. The incubation period of trichophytosis under natural conditions was reported by some writers to be as long as 4 to 6 weeks (Edwardson and Andrews 1979). The cases of fully developed signs of trichophytosis among calves at the time that vaccination against trichophytosis is under way (at about 1 month of age) are therefore no solitary findings. This fact gave an impetus to experiments designed to test the efficacy of vaccination of calves against trichophytosis as early as a few days after birth.

Yablochnick et al. (1987) carried out an experiment on 100 calves divided into 5 groups of animals aged 3 to 5,6 to 10,11 to 20,21 to 29 and 30 to 40 days. The calves were vaccinated with vaccine LTF-130 and revaccinated 10 days later. Two weeks afterwards the vaccinated calves, and 27 non-vaccinated controls, were placed among young cattle affected with clinical trichophytosis. During the following 6-month observation period none of the vaccinated calves developed trichophytosis, whereas 22 of the 27 controls became clinically ill. The development of post-vaccination immunity in young calves was confirmed by the afore-mentioned writers in challenge experiments and in subsequent field experiments comprising 685 head of young cattle.

Our experiments yielded similar results. The vaccination conferred a satisfactory degree of immunity against experimental infection to all vaccinated calves including those vaccinated at 1 day of age. After challenge, the vaccinated calves (a total of 88 animals) either did not develop trichophytosis at all or showed only minute superficial dermal changes of short duration. All the 48 non-vaccinated controls challenged with the same dose developed trichophytosis manifested by deep confluent lesions covering a large part of the inoculated skin. This shows that the challenge dose was high and the prophylatic efficacy of the vaccine was good. 
The incidence of the first mycotic lesions in control calves was recorded between 8 and 16 days after inoculation of the infectious agent. This is in keeping with the observations of Lepper (1972) who reported that clinical signs of trichophytosis were first observed 7 days but mostly as many as 14 to 17 days after inoculation of $T$. verrucosum culture.

In our field experiment where the first vaccination dose was administered to calves 3 to 6 days old only $4(2.2 \%)$ of the 179 calves became ill in the infected environment. This result can be regarded as a great success considering that before the start of our experiment the proportion of calves of the same age category in this herd where calves had been vaccinated at 4 to 6 weeks of age was as high as $50 \%$.

From the data reported here it is evident that a satisfactory degree of protection of calves against trichophytosis can be achieved even when the immunization is started a few days after birth. In our previous experiments the interval between revaccination with the Czechoslovak vaccine and the development of satisfactory immunity was found to be 21 to 28 days (Rybnikár et al. 1989). From this it appears that a reliable post-vaccination protection of bovine herds against trichophytosis can be assured in calves from 1 month of age at the earliest.

Immunization of calves a few days after birth is recommendable in trichophytic foci where animals of the youngest age categories are affected. In herds. where trichophytosis has been brought under control a better strategy would be to vaccinate calves at 1 to 2 months of age after they are moved to calf-houses.

Table 1

Test of the efficacy of the vaccine against trichophytosis in calves vaccinated at 1 to 7 days of age and revaccinated 10 days later

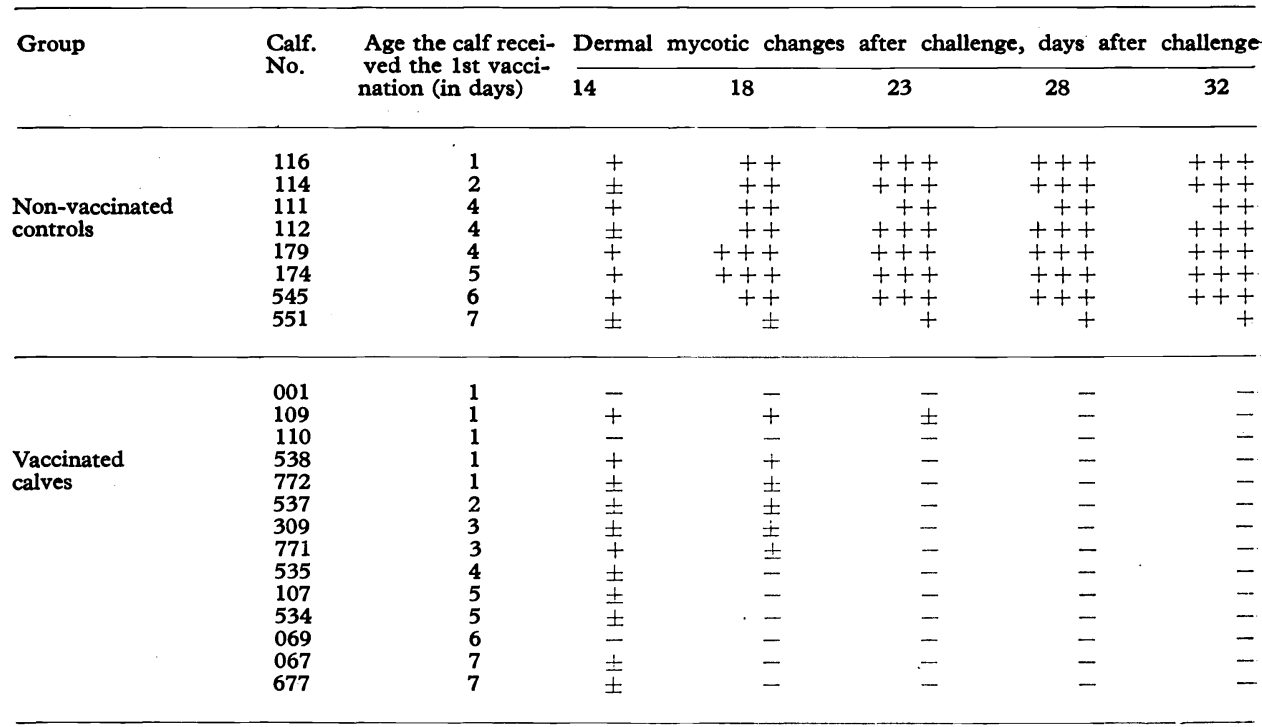

- No dermal mycotic changes

\pm Minute dermal changes - scales, papillae

+ Solitary mycotic foci

++ Mycotic foci covering more than a quarter of the inoculated area

+++ Mycotic foci covering more than half of the inoculated area 
Table 2

Test of the efficacy of the vaccine against trichophytosis in calves vaccinated at 8 to 14 days of age and revaccinated 10 days later

\begin{tabular}{|c|c|c|c|c|c|c|c|}
\hline \multirow[t]{2}{*}{ Group } & \multirow{2}{*}{$\begin{array}{l}\text { Calf } \\
\text { No. }\end{array}$} & \multirow{2}{*}{$\begin{array}{l}\text { Age the calf recei- } \\
\text { ved the } 1 \text { st vacci- } \\
\text { nation (in days) }\end{array}$} & \multicolumn{2}{|c|}{ Dermal mycotic changes } & after challenge, & , days after & \multirow{2}{*}{$\frac{\text { challenge }}{32}$} \\
\hline & & & 14 & 18 & 23 & 28 & \\
\hline $\begin{array}{l}\text { Non-vaccinated } \\
\text { controls }\end{array}$ & $\begin{array}{l}325 \\
326 \\
324 \\
225 \\
224 \\
396 \\
394 \\
552\end{array}$ & $\begin{array}{r}8 \\
8 \\
9 \\
9 \\
10 \\
11 \\
12 \\
14\end{array}$ & $\begin{array}{l}+ \\
+ \\
+ \\
\bar{t} \\
\pm \\
+ \\
\pm \\
+\end{array}$ & $\begin{array}{r}++ \\
++ \\
++ \\
+ \\
++ \\
++ \\
+ \\
++\end{array}$ & $\begin{array}{r}+t \\
++ \\
+++ \\
++ \\
++t \\
+++ \\
+ \\
+++\end{array}$ & $\begin{array}{r}++ \\
++ \\
+++ \\
++ \\
+++ \\
+++ \\
+ \\
++\end{array}$ & $\begin{array}{r}++ \\
++ \\
+++ \\
+++ \\
+++ \\
+++ \\
++ \\
++\end{array}$ \\
\hline $\begin{array}{l}\text { Vaccinated } \\
\text { calves }\end{array}$ & $\begin{array}{l}684 \\
685 \\
769 \\
770 \\
511 \\
530 \\
682 \\
542 \\
676 \\
853 \\
675 \\
852 \\
468 \\
509 \\
510 \\
518 \\
519 \\
714\end{array}$ & $\begin{array}{r}8 \\
8 \\
8 \\
8 \\
10 \\
11 \\
11 \\
12 \\
12 \\
12 \\
13 \\
13 \\
14 \\
14 \\
14 \\
14 \\
14 \\
14\end{array}$ & $\begin{array}{r}- \\
\overline{+} \\
++ \\
+ \\
- \\
\overline{+} \\
\overline{+} \\
+ \\
\pm \\
\pm \\
+ \\
\pm \\
\pm \\
\pm \\
\pm \\
+\end{array}$ & $\begin{array}{r}- \\
\pm \\
+ \\
\pm \\
\pm \\
\pm \\
\pm \\
- \pm \\
\pm \\
\pm \\
\pm \\
\pm \\
\pm \\
\pm \\
\pm \\
\pm\end{array}$ & $\begin{array}{l}- \\
\pm \\
\pm \\
\pm \\
\pm \\
- \\
\pm \\
\pm \\
- \\
- \\
- \\
- \\
\pm \\
\pm \\
\pm \\
\pm \\
-\end{array}$ & $\begin{array}{l}- \\
= \\
= \\
= \\
= \\
\pm \\
= \\
- \\
- \\
-- \\
- \\
\pm \\
\pm \\
\pm\end{array}$ & $\begin{array}{l}\overline{-} \\
\bar{z} \\
\overline{-} \\
\overline{-} \\
\overline{-} \\
\overline{-} \\
\overline{-} \\
\overline{-} \\
\overline{-} \\
\overline{-} \\
\overline{-}\end{array}$ \\
\hline
\end{tabular}

For explanation of the signs,,,- \pm+++ and +++ see Table 1.

Table 3

Test of the efficacy of the vaccine against trichophytosis in calves vaccinated at 15 to 21 days of age and revaccinated 10 days later

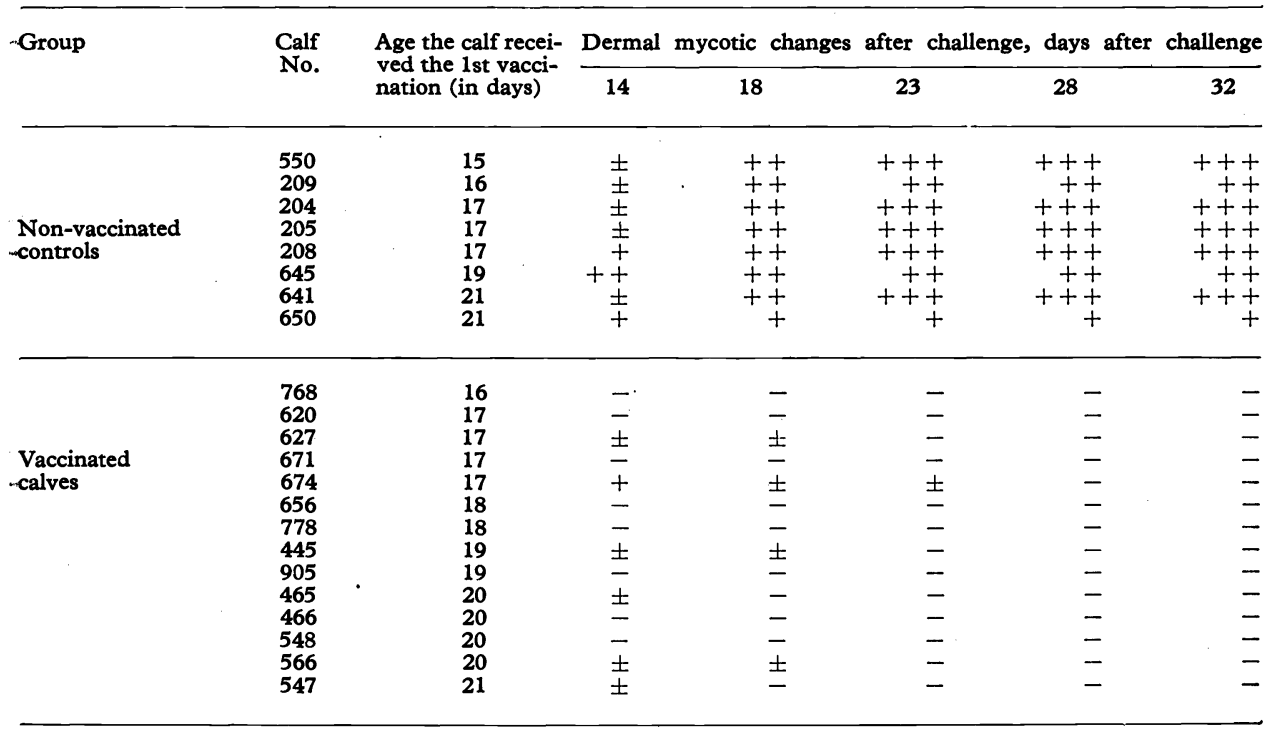

For explanation of the signs,,,- \pm+++ and +++ see Table 1. 
Table 4

Test of the efficacy of the vaccine against trichophytosis in calves vaccinated at 22 to 28 days of age and revaccinated 10 days later

\begin{tabular}{|c|c|c|c|c|c|c|c|}
\hline \multirow[t]{2}{*}{ Group } & \multirow{2}{*}{$\begin{array}{l}\text { Calf } \\
\text { No. }\end{array}$} & \multirow{2}{*}{$\begin{array}{l}\text { Age the calf recei- } \\
\text { ved the 1st vacci- } \\
\text { nation (in days) }\end{array}$} & \multicolumn{2}{|c|}{ Dermal mycotic changes } & after challenge, & days after & \multirow{2}{*}{$\frac{\text { challenge }}{32}$} \\
\hline & & & 14 & 18 & 23 & 28 & \\
\hline $\begin{array}{l}\text { Non-vaccinated } \\
\text { controls } \\
\end{array}$ & $\begin{array}{l}504 \\
506 \\
989 \\
986 \\
987 \\
106 \\
104 \\
105\end{array}$ & $\begin{array}{l}23 \\
23 \\
24 \\
25 \\
25 \\
26 \\
27 \\
27\end{array}$ & $\begin{array}{r} \pm \\
+ \pm \\
\pm \\
= \\
- \\
- \\
\pm\end{array}$ & $\begin{array}{r}++ \\
++ \\
++ \\
++ \\
+ \\
\pm \\
+ \\
++\end{array}$ & $\begin{array}{c}++ \\
+++ \\
+++ \\
++ \\
++ \\
++ \\
++ \\
++\end{array}$ & $\begin{array}{r}++ \\
+++ \\
+++ \\
++ \\
++ \\
++ \\
+++ \\
+++\end{array}$ & $\begin{array}{r}++ \\
+++ \\
++ \\
++ \\
++ \\
+++ \\
+++ \\
+++\end{array}$ \\
\hline $\begin{array}{l}\text { Vaccinated } \\
\text { calves }\end{array}$ & $\begin{array}{l}618 \\
442 \\
543 \\
450 \\
669 \\
670 \\
775 \\
056 \\
539 \\
038 \\
668 \\
564 \\
577 \\
878\end{array}$ & $\begin{array}{l}22 \\
23 \\
23 \\
24 \\
24 \\
24 \\
24 \\
25 \\
26 \\
27 \\
27 \\
28 \\
28 \\
28\end{array}$ & $\begin{array}{l}+ \\
= \\
= \\
- \\
= \\
= \\
\pm \\
\pm \\
\pm \\
\pm \\
+\end{array}$ & $\begin{array}{l} \pm \\
- \\
- \\
- \\
- \\
- \\
\pm \\
\pm \\
\pm \\
\overline{ \pm} \\
+\end{array}$ & $\begin{array}{l}- \\
\overline{-} \\
- \\
\overline{-} \\
\overline{-} \\
\overline{ \pm} \\
\overline{-} \\
\overline{-} \\
\overline{ \pm}\end{array}$ & $\begin{array}{l}- \\
- \\
- \\
- \\
- \\
= \\
= \\
- \\
- \\
= \\
-\end{array}$ & $\begin{array}{l}- \\
\bar{z} \\
\overline{-} \\
\overline{-} \\
\overline{-} \\
\overline{-} \\
\overline{-} \\
\overline{-} \\
\overline{-}\end{array}$ \\
\hline
\end{tabular}

For explanation of the signs,,,- \pm+++ and +++ see Table 1.

Table 5

Test of the efficacy of the vaccine against trichophytosis in calves vaccinated at 29 to 35 days of age and revaccinated 10 days later

\begin{tabular}{|c|c|c|c|c|c|c|c|}
\hline \multirow[t]{2}{*}{ Group } & \multirow{2}{*}{$\begin{array}{l}\text { Calf } \\
\text { No. }\end{array}$} & \multirow{2}{*}{$\begin{array}{l}\text { Age the calf recei- } \\
\text { ved the 1st vacci- } \\
\text { nation (in days) }\end{array}$} & \multicolumn{2}{|c|}{ Dermal mycotic changes } & after challenge, & days after & \multirow{2}{*}{$\frac{\text { challenge }}{32}$} \\
\hline & & & 14 & 18 & 23 & 28 & \\
\hline $\begin{array}{l}\text { Non-vaccinated } \\
\text { controls }\end{array}$ & $\begin{array}{l}101 \\
103 \\
100 \\
533 \\
532 \\
093 \\
529 \\
223\end{array}$ & $\begin{array}{l}29 \\
29 \\
30 \\
31 \\
32 \\
33 \\
33 \\
35\end{array}$ & $\begin{array}{l} \pm \\
\pm \\
\pm \\
\pm \\
\pm \\
\pm \\
\pm\end{array}$ & $\begin{array}{r}+ \\
+ \\
++ \\
+ \\
++ \\
+ \\
++ \\
+\end{array}$ & $\begin{array}{r}++ \\
++ \\
+++ \\
+++ \\
+++ \\
++ \\
+++ \\
++\end{array}$ & $\begin{array}{c}+++ \\
+++ \\
+++ \\
+++ \\
+++ \\
++ \\
+++ \\
++\end{array}$ & $\begin{array}{r}+++ \\
+++ \\
+++ \\
+++ \\
+++ \\
++ \\
+++ \\
++\end{array}$ \\
\hline $\begin{array}{l}\text { Vaccinated } \\
\text { calves }\end{array}$ & $\begin{array}{l}451 \\
575 \\
576 \\
578 \\
667 \\
533 \\
799 \\
938 \\
581 \\
607 \\
617 \\
242 \\
821 \\
932\end{array}$ & $\begin{array}{l}29 \\
29 \\
29 \\
29 \\
29 \\
30 \\
30 \\
30 \\
31 \\
32 \\
33 \\
34 \\
35 \\
35\end{array}$ & $\begin{array}{l}+ \\
\pm \\
- \\
\overline{ \pm} \\
\pm \\
\pm \\
+ \\
+ \\
- \\
\overline{-} \\
\overline{+} \\
+ \\
+ \\
\pm\end{array}$ & $\begin{array}{l} \pm \\
- \\
- \\
\pm \\
\overline{ \pm} \\
\pm \\
\pm \\
- \\
- \\
\pm \\
\pm \\
\pm\end{array}$ & $\begin{array}{l}\bar{z} \\
\overline{-} \\
\overline{-} \\
\bar{z} \\
\overline{ \pm} \\
\pm \\
\overline{-} \\
\bar{z} \\
\pm \\
\overline{ \pm}\end{array}$ & $\begin{array}{l}\bar{z} \\
\overline{-} \\
\bar{z} \\
\bar{z} \\
\bar{z} \\
\overline{-} \\
\bar{z} \\
\bar{z} \\
\overline{-}\end{array}$ & $\begin{array}{l}\bar{z} \\
\overline{-} \\
\overline{-} \\
\bar{z} \\
\overline{-} \\
\overline{-} \\
\overline{-} \\
\overline{-}\end{array}$ \\
\hline
\end{tabular}

For explanation of the signs,,,- \pm+++ and +++ see Table 1 . 
Table 6

Test of the efficacy of the vaccine against trichophytosis in calves vaccinated at 36 to 42 days of age and revaccinated 10 days later

\begin{tabular}{|c|c|c|c|c|c|c|c|}
\hline \multirow[t]{2}{*}{ Group } & \multirow{2}{*}{$\begin{array}{l}\text { Calf } \\
\text { No. }\end{array}$} & \multirow{2}{*}{$\begin{array}{l}\text { Age the calf recei- } \\
\text { ved the 1st vacci- } \\
\text { nation (in days) }\end{array}$} & \multicolumn{2}{|c|}{ Dermal mycotic changes } & after challenge, & , days after & \multirow{2}{*}{ challenge } \\
\hline & & & 14 & 18 & 23 & 28 & \\
\hline $\begin{array}{l}\text { Non-vaccinated } \\
\text { controls }\end{array}$ & $\begin{array}{l}456 \\
868 \\
826 \\
867 \\
825 \\
824 \\
816 \\
817\end{array}$ & $\begin{array}{l}36 \\
36 \\
38 \\
38 \\
39 \\
40 \\
41 \\
41\end{array}$ & $\begin{array}{c}+ \\
\pm \\
\pm \\
\pm \\
+ \\
+ \\
+\end{array}$ & $\begin{array}{r}+t \\
\pm \\
+ \\
++ \\
++ \\
++ \\
+ \\
++\end{array}$ & $\begin{array}{r}++ \\
++ \\
++ \\
++ \\
+++ \\
+++ \\
+ \\
++\end{array}$ & $\begin{array}{r}++ \\
++ \\
+++ \\
++t \\
+++ \\
+++ \\
++ \\
+++\end{array}$ & $\begin{array}{r}++ \\
++ \\
+++ \\
+++ \\
+++ \\
+++ \\
++ \\
+++\end{array}$ \\
\hline \multirow{2}{*}{$\begin{array}{l}\text { Vaccinated } \\
\text { calves }\end{array}$} & $\begin{array}{l}062 \\
117 \\
546 \\
060 \\
061 \\
673\end{array}$ & $\begin{array}{l}36 \\
36 \\
36 \\
37 \\
37 \\
37\end{array}$ & $\begin{array}{l}+ \\
+ \\
+ \\
- \\
+\end{array}$ & $\begin{array}{l} \pm \\
\pm \\
- \\
- \\
-\end{array}$ & $\begin{array}{l} \pm \\
- \\
- \\
- \\
-\end{array}$ & $\begin{array}{l}- \\
- \\
- \\
- \\
-\end{array}$ & $\begin{array}{l}- \\
- \\
- \\
-\end{array}$ \\
\hline & $\begin{array}{l}058 \\
929 \\
055 \\
170 \\
556 \\
769 \\
311 \\
823\end{array}$ & $\begin{array}{l}38 \\
38 \\
40 \\
40 \\
40 \\
41 \\
42 \\
42\end{array}$ & $\begin{array}{l}- \\
\pm \\
\pm \\
\overline{ \pm} \\
\pm \\
\pm \\
\pm\end{array}$ & $\begin{array}{l}- \\
\pm \\
- \\
\bar{t} \\
-\end{array}$ & $\begin{array}{l}- \\
\overline{-} \\
\overline{-} \\
\pm \\
\overline{-}\end{array}$ & $\begin{array}{l}- \\
- \\
\overline{-} \\
\overline{-} \\
- \\
-\end{array}$ & $\begin{array}{l}- \\
= \\
= \\
= \\
=\end{array}$ \\
\hline
\end{tabular}

For explanation of the signs,,,- \pm+++ and +++ see Table 1.

\section{Vakcinace mladých telat proti trichofytóze}

Telata vakcinovaná proti trichofytóze poprvé ve věku 1 až 7 dnů s revakcinací po deseti dnech prokázala dostatečnou chráněnost proti experimentálnímu nakaženi virulentním kmenem Trichophyton verrucosum. Stejné výsledky byly dosaženy po imunizaci zvírat dalších věkových kategorií (8 až 42 dnů). U všech kontrolních nevakcinovaných telat došlo po aplikaci stejné čelenžní dávky ke vzniku rozsáhlých trichofytických krust, které přetrvávaly po celou dobu pozorování.

Terénní pokus byl proveden $\mathrm{v}$ chovu $\mathrm{s}$ výskytem trichofytózy u $50 \%$ telat. Nově ustájené kusy byly vakcinovány ve věku 3 až 6 dnů a revakcinovány po deseti dnech. Ze 179 imunizovaných zvírat onemocněla 4 telata $(2,2 \%)$.

\section{Вакцинирование молодых телят противотрихофитозной вакциной}

Вакцинированные противотрихофитозной вакциной телята впервые в возрасте 1-7 суток с повторным вакцинированием спустя 10 суток выявило достаточную защиту против экспериментального заряжения вирулентным штаммом Trichophyton verrucosum. Одинаковых peзультатов было достигнуто после иммунизации животных других возрастных категорий (8-42 суток). У всех контрольных, не проходивших вакцинированием телят, после применения одинаковой партии дозы возникли многочисленные трихофитические корки, имеющие место в течение всего периода наблюдения.

Эксперимент в полевых условиях проводили на животноводстве 
с наличием трихофитоза у $50 \%$ телят. Новые поступившие особи вакцинировали в возрасте 3-6 суток и повторно вакцинировали через 10 суток. Из общего числа 179 иммунизированных животных заболели 4 телята $(2,2 \%)$.

\section{References}

EDWARDSON, J.-ANDREWS, A. H.: An outbreak of ringworm in a group of young cattle. Vet. Rec., 104, 1979: 474-477

LEPPER, A. W. D.: Experimental bovine Trichophyton verrucosum infection. Preliminary clinical, immunological and histological observations in primarily infected and reinoculated cattle. Res. vet. Sci., 13, 1972: 105-115

NAESS, B. - SANDVIK, O.: Early vaccination of calves against ringworm caused by Trichophyton verrucosum. Vet. Rec., 109, 1981: 199-200

RYBNIKÁR, A.-CHUMELA, J. - VRZAL, V.: Vznik imunity po vakcinaci skotu proti trichofytóze. Veter. Med. (Praha), 34, 1989: 97-100

SARKISOV, A. CH.: Specificeskaja profilaktika trichofitii krupnogo rogatogo skota. Veterinarija (Moskva), 1979, (1): 40-41

SARKISOV, A. CH.-NIKIFOROV, L. I.-PRITULA, A. S.-PETROVICH, S. V.-JILAVJAN, H. A.: Suchaja vakcina LTF-130 protiv striguščego lišaja krupnogo rogatogo skota. Bjul. Vses. ord. Lenina inst. eksper. vet., 25, 1976: 7-10

YABLOCHNICK, L. M.-ZHARKOV, I. I.-SAKARAŠVILI, N. R.-CURKAN, M. A.SEKIR, N. A.-KICIN, I. K.-KALUŽAK, I. N.: Immunizacija teljat protiv trichofitii. Veterinarija (Moskva), 1987, (4): 27-29

ZHARKOV, I. I.: Effektivnost immunoprofilaktiki trichofitii. Veterinarija (Moskva), 1985, (11): $22-23$ 


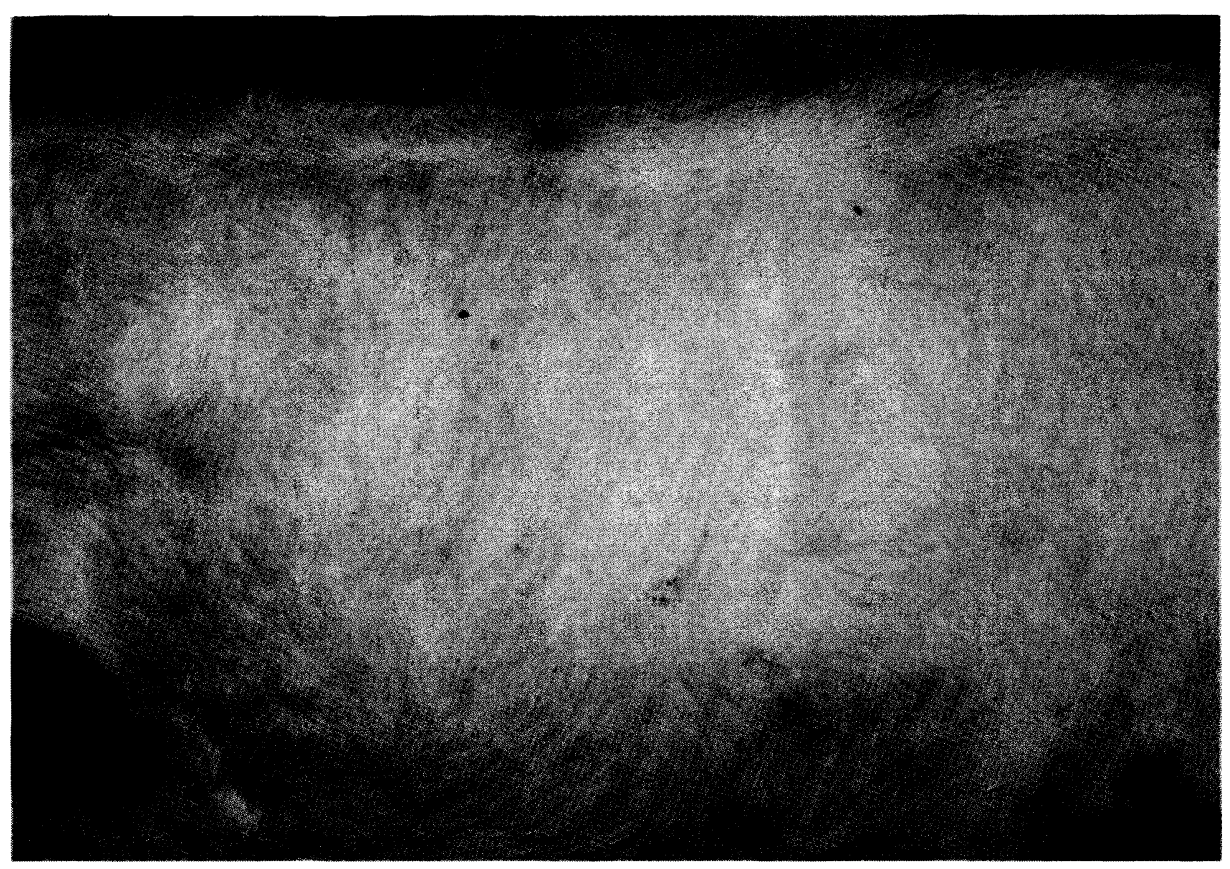

Fig. 1: Vaccinated calf No. 548, 32 days after challenge.

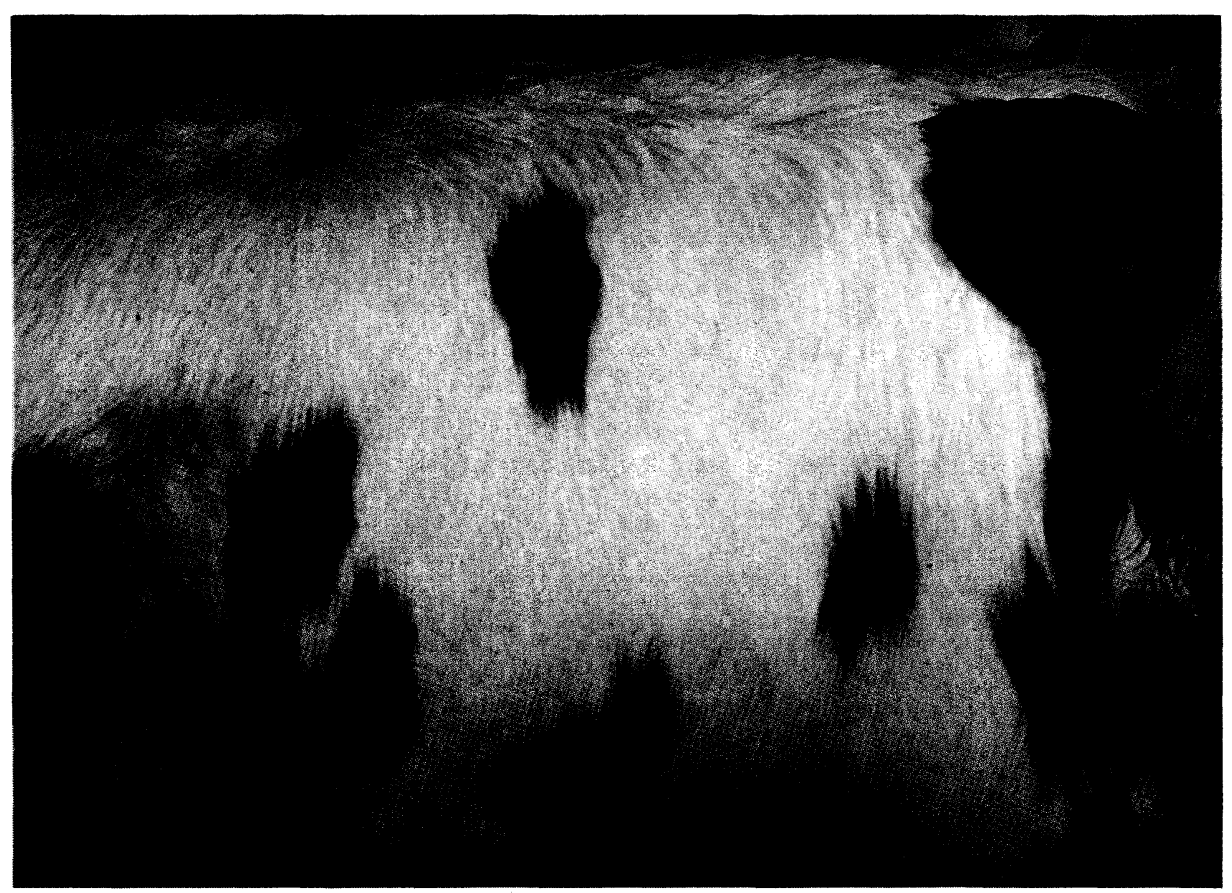

Fig. 2: Vaccinated calf No. 821, 32 days after challenge. 


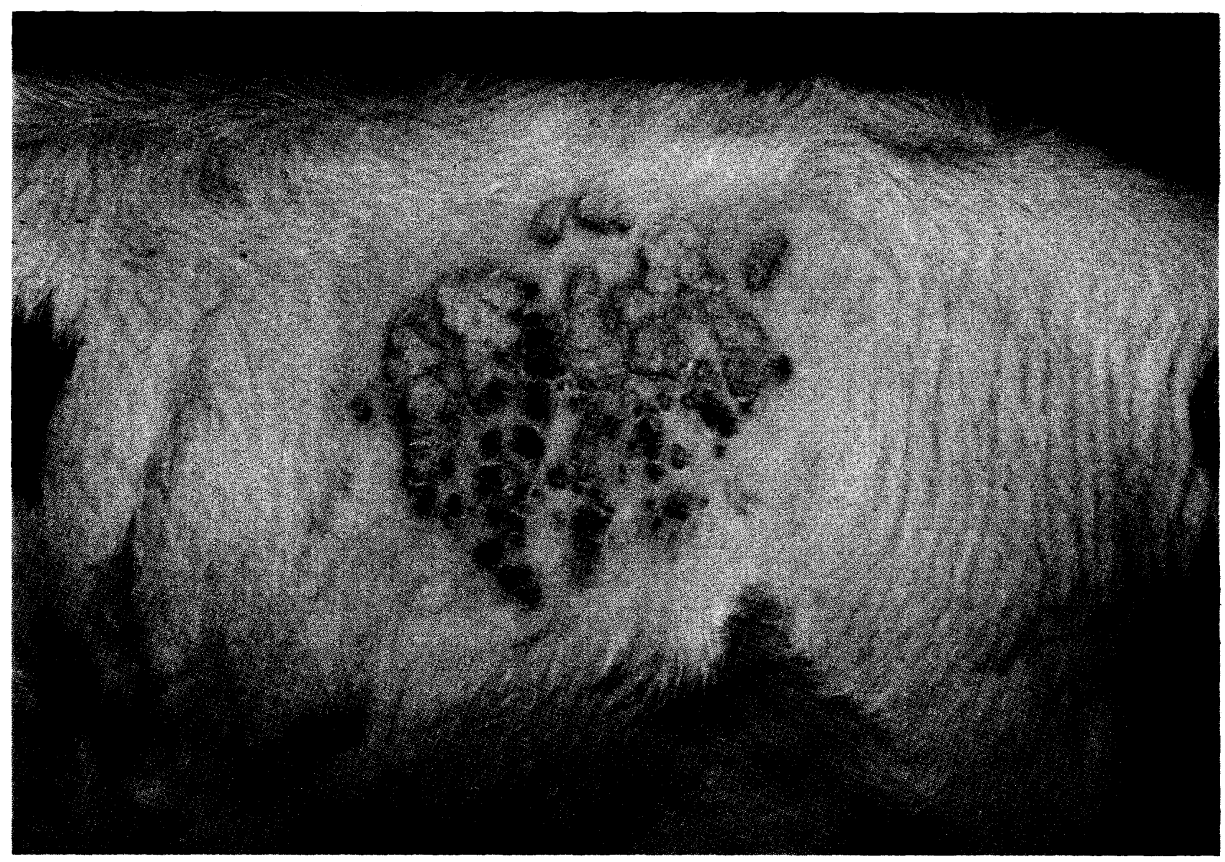

Fig. 3: Control non-vaccinated calf No. 545, 32 days after challenge.

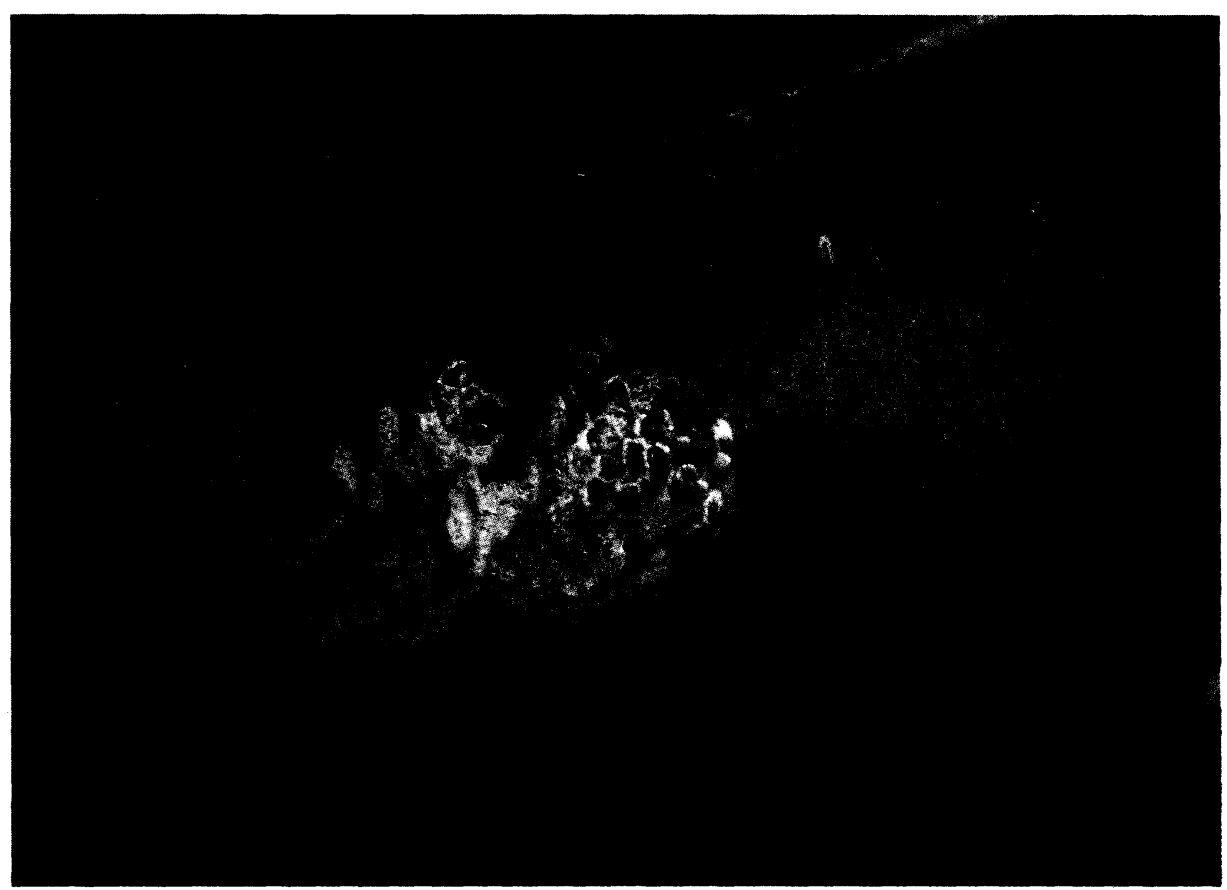

Fig. 4: Control non-vaccinated calf No. 223, 32 days after challenge. 